ESSENTIALS OF PALEOMAGNETISM 
This page intentionally left blank 


\title{
ESSENTIALS OF PALEOMAGNETISM
}

\author{
LIS A TAUXE
}

With Contributions from

Robert F. Butler, R. Van der Voo, and Subir K. Banerjee

— University of California Press Berkeley Los Angeles London 
University of California Press, one of the most distinguished university presses in the United States, enriches lives around the world by advancing scholarship in the humanities, social sciences, and natural sciences. Its activities are supported by the UC Press Foundation and by philanthropic contributions from individuals and institutions. For more information, visit www.ucpress.edu.

Digital edition available at UC Press Website.

University of California Press

Berkeley and Los Angeles, California

University of California Press, Ltd.

London, England

(C) 2010 by The Regents of the University of California

Library of Congress Cataloging-in-Publication Data

Tauxe, Lisa.

Essentials of paleomagnetism / Lisa Tauxe; with contributions from Robert F. Butler, R. Van der Voo, and Subir K. Banerjee.

p. $\mathrm{cm}$.

Includes index.

ISBN 978-0-520-26031-3 (pbk. : alk. paper)

1. Paleomagnetism. I. Title.

QE501.4.P35T3835 2010

$538.727-\mathrm{dc} 22$

2010030689

Manufactured in China

$\begin{array}{rlllllllll}18 & 17 & 16 & 15 & 14 & 13 & 12 & 11 & 10 \\ 10 & 9 & 8 & 7 & 6 & 5 & 4 & 3 & 2 & 1\end{array}$

The paper used in this publication meets the minimum requirements of ANSI/NISO Z39.48-1992 (R 1997)(Permanence of Paper).

Cover: All photos but one by Lisa Tauxe. Third photo in row by Daniel Staudigel. 